\title{
Five Grade 7 learners' understanding of comprehension skills at a quintile 5 school in South Africa
}

\begin{tabular}{|c|c|}
\hline \multicolumn{2}{|c|}{$\begin{array}{l}\text { Authors: } \\
\text { Nomonde Ntshikila }{ }^{1} \text { (D) } \\
\text { Janet L. Condy }{ }^{1} \text { (D) } \\
\text { Lawrence Meda }^{2} \text { (D) } \\
\text { Heather N. Phillips }\end{array}$} \\
\hline \multicolumn{2}{|c|}{$\begin{array}{l}\text { Affiliations: } \\
{ }^{1} \text { Research Department, } \\
\text { Faculty of Education, Cape } \\
\text { Peninsula University of } \\
\text { Technology, Cape Town, } \\
\text { South Africa }\end{array}$} \\
\hline \multicolumn{2}{|c|}{$\begin{array}{l}{ }^{2} \text { Research Department, } \\
\text { Faculty of Education, Zayed } \\
\text { University, Dubai, United } \\
\text { Arab Emirates }\end{array}$} \\
\hline \multicolumn{2}{|c|}{$\begin{array}{l}\text { Corresponding author: } \\
\text { Janet Condy, } \\
\text { condyj@cput.ac.za }\end{array}$} \\
\hline \multicolumn{2}{|c|}{$\begin{array}{l}\text { Dates: } \\
\text { Received: } 24 \text { June } 2021 \\
\text { Accepted: } 01 \text { Dec. } 2021 \\
\text { Published: } 24 \text { Feb. } 2022\end{array}$} \\
\hline \multicolumn{2}{|c|}{$\begin{array}{l}\text { How to cite this article: } \\
\text { Ntshikila, N., Condy, J.L., } \\
\text { Meda, L. \& Phillips, H.N., } \\
\text { 2022, 'Five Grade } 7 \text { learners' } \\
\text { understanding of } \\
\text { comprehension skills at a } \\
\text { quintile } 5 \text { school in South } \\
\text { Africa', Reading \& Writing } \\
\text { 13(1), a324. https://doi. } \\
\text { org/10.4102/rw.v13i1.324 }\end{array}$} \\
\hline \multicolumn{2}{|c|}{$\begin{array}{l}\text { Copyright: } \\
\text { (C) 2022. The Authors. } \\
\text { Licensee: AOSIS. This } \\
\text { is licensed under the } \\
\text { Creative Commons } \\
\text { Attribution License. }\end{array}$} \\
\hline \multicolumn{2}{|l|}{ Read online: } \\
\hline 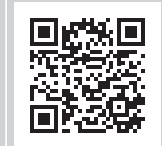 & $\begin{array}{l}\text { Scan this QR } \\
\text { code with your } \\
\text { smart phone or } \\
\text { mobile device } \\
\text { to read online. }\end{array}$ \\
\hline
\end{tabular}

Background: Research into language and reading scores show that South African learners struggle to read for meaning. Many local researchers report on the inadequate teaching training programmes. Teachers cannot teach basic comprehenion skills.

Objectives: This research identifies a gap in the research and records an intervention programme designed to engage learners and develop their higher-order comprehension abilities. This research analyses responses from five learners who engaged in a variety of literacy activities to extend their zones of literacy abilities to become independent critical thinkers.

Method: An interpretivist paradigm, within a qualitative approach, using a case study design was devised and implemented. Five struggling Grade 7 learners were purposively selected to participate in a 10-week intervention programme. Data were collected using pre-tests and post-tests and the learners' own exercise books to assess their academic performance in written comprehensions, their daily comments on their motivation charts, information from two interviews and the researchers' participant observation scheduled notes.

Results: During the time of the intervention, all five Grade 7 learners gradually learned and began to use higher-order thinking skills.

Conclusion: This small research project indicates that when a teacher explicitly planned and used a variety of literacy strategies to teach comprehension skills, not only did the learners enjoy the respectful discussions but this experience developed them into independent higherorder thinkers.

Keywords: cognitive thinking; critical thinking; qualitative research; zones of ability; higherorder thinking skills; intervention programme.

\section{Introduction}

For economic development, stability in the labour market as well as sustainable lifelong learning, basic literacy skills are a prerequisite (Radhamoney \& Hugo 2020). As suggested by the Sustainable Development Goals (Statistics South Africa [SA] 2019:21) quality education is necessary 'to empower people to achieve their dreams for economic advancement'. However, the postapartheid democratic educational policies developed in 1994 have resulted in little change for high poverty communities, with the persistent continuation of unequal schooling. The complex nature of our relentless low literacy rates is influenced by pedagogical approaches, language differences and socio-economic factors.

To sustain the parameters of a racist state, pedagogy was strongly behaviourist in nature. Black learners were expected to learn information, obey and repeat the prescribed information. They had to mimic teachers and give back the texts in their original form, undermining the reading and comprehension skills of many Black learners in South African schools. The lack of reading was more prevalent in poor communities where parents of learners were often 'unable to read and write' (Völkel et al. 2016:13) with their children reading and writing at a functional level (Howie et al. 2017). To compound this complexity, the Amended Curriculum and Assessment Policy Statement (CAPS) (2019) provides a curriculum that does not take into account the extreme poverty levels found in many township schools (Pretorius \& Klapwijk 2016). Since there are few and unsuitable resources available in these schools (Brink, Motolo \& Henning 2021; Spaull, Pretorius \& Mohohlwane 2020), teachers rely heavily on textbooks which encourages memorisation and a lack of higher-order criticality, and denies learners a safe space for debating and creativity. Despite a plethora of initiatives to introduce constructivist pedagogies, and provide all schools with a variety of resources in different languages to encourage questioning, critical thinking and 
mutual discovery of knowledge, the South African education system continues to experience many literacy challenges (Völkel et al. 2016).

The 11 official languages in South Africa is yet another sensitive issue, particularly when there is a discrepancy between the home language of the learners and the language of the tests (Van Staden 2016). The Language in Education Policy (LiEP) attempts to address these language tensions and inequalities by acknowledging that our cultural diversity is a national asset (Mothata \& Lemmer 2002). Van Staden (2016:2) argues that this policy promotes multilingualism by maintaining 'home language(s) while providing access to effective acquisition of additional languages'. Around $70 \%$ of primary schools in South Africa complete their first three years of schooling in their African home language, with English taught as an additional language (Pretorius \& Spaull 2016:1450). Yet from Grade 4, 90\% of all teaching and learning is conducted in English. Howie et al. (2017:94) indicated that in the Progress in International Reading Literacy Study (PIRLS) 2016 assessments, for Grade 4 learners, the average nine official African languages scores were considerably lower than those for English and Afrikaans and when learners were tested in their own language they 'achieved a higher mean score'.

Over the years, many isiXhosa speaking learners have migrated from the Eastern Cape for better educational and career opportunities and in 2019 in the Western Cape, there were almost equal numbers of English and isiXhosa speaking learners (Cornelissen 2021) with fewer Afrikaans speaking learners. In an attempt to provide an equal education system, the Western Cape Education Department (WCED) have been conducting Systemic Tests in Language and Mathematics, with Grade 3 and Grade 6 learners (from 2002), and more recently in 2010 with Grade 9 learners in the three official languages of this province: English, Afrikaans and isiXhosa. Schools use these results diagnostically to identify areas of improvement and for the WCED to provide necessary and appropriate support. The 2019 Grade 6 systemic test results for performance in cognitive levels tested by language of learning and teaching (LoLT) particularly 'language' are shown in Table 1. Analysing the sub-components of reading, the isiXhosa results, for all aspects of literacy comprehension (literal, inferential, evaluative and knowledge recall) as well as the overall reading and viewing results, are much lower for Black learners than for the Afrikaans and English speaking learners. Evaluative comprehension is particularly low for isiXhosa speaking learners where the pass percentage is a mere $16.1 \%$. Conversely, Howie et al. (2017) states that, where schools focus on academic success, a positive school environment, an abundance of resources and better trained teachers, learners realise higher reading achievements.

Today, many parents, who are themselves uneducated (Pretorius \& Klapwijk 2016) require their children to have a better education and choose to send them away from township schools, to suburban schools where not only is the teaching and learning conducted in English, but the results are much better. They regard such schools as a means to social mobility and English has become a prestige language. As a result, their children are learning in a language with which they are unfamiliar, their parents cannot support them and this results in their children's inability to acquire basic comprehension skills.

Many of these schools are quintile 5 schools, which means they are fee-paying and receive the lowest funding from the government because of the high economic status of the neighbouring community (Eadie et al. 2021). However, this is an incorrect picture due to the high migration rate of families into the suburban schools (Ogbonnaya \& Awuah 2019:2). Despite the Global Education Monitoring Report: 2030 Agenda (UNESCO 2018), which is to 'leave no one behind', it appears that for the isiXhosa speaking community, historical disadvantages persist. All these issues contribute to reinforcing the generational cycle of poverty.

\section{Significance of the study}

The Western Cape systemic tests include the following four comprehension skills: (1) focus on and retrieve explicitly stated information, (2) making straightforward inferences, (3) interpret and integrate ideas and information, and (4) evaluate and examine content, language and textual elements (Howie et al. 2017). The PIRLS 2016 report claims that South African Grade 4 learners achieved best at the lowest level comprehension skill, 'focus on and retrieve explicitly stated information', rather than the other three comprehension skills which require higher-order critical thinking.

There have been many research studies conducted in how comprehension skills are taught in South Africa (Pretorius \& Spaull 2016; Statistics SA 2019; Taylor 2014; Van der Berg et al. 2016) but there has been a dearth of research conducted on teaching comprehension skills in an urban public mainstream quintile 5 school. This school is situated in a mixed socio-economic environment, inclusive of poor to wealthy families. According to Bassadien and Spencer (2016:2), 'higher income residents replace lower-income residents' and this is true for this school. Many people have relocated because of high interest rates in this area and wealthier people have bought their homes. At the same time, and in the same area, there are many people who live on the streets, in backyards and in tin houses, whose children attend this school.

This journal article emanated from a full master's thesis; yet here the researcher focuses on only one of the research questions: 'What effect did an eight-week IP have on the five Grade 7 learners' comprehension abilities?' Two subquestions guided this study:

- How did the intervention programme (IP) assist five Grade 7 learners to develop their higher-order thinking comprehension skills?

- How did the learners develop cognitively during the IP? 
TABLE 1: The results of the 2019 Grade 6 Western Cape Education Department systemic testing in language.

\begin{tabular}{|c|c|c|c|c|c|c|c|}
\hline \multicolumn{8}{|c|}{ Performance in cognitive levels tested by LoLT } \\
\hline LoLT & Home language & $\begin{array}{l}\text { Number of learners } \\
2019\end{array}$ & $\begin{array}{c}\text { Literal comprehension } \\
\text { Pass \% }\end{array}$ & $\begin{array}{c}\text { Inferential } \\
\text { comprehension } \\
\text { Pass } \%\end{array}$ & $\begin{array}{c}\text { Evaluative } \\
\text { comprehension } \\
\text { Pass } \%\end{array}$ & $\begin{array}{c}\text { Knowledge recall } \\
\text { Pass } \%\end{array}$ & $\begin{array}{c}\text { Reading and viewing } \\
\text { Pass \% }\end{array}$ \\
\hline \multirow[t]{3}{*}{ English } & Afrikaans & 882 & 69.3 & 34.0 & 22.7 & 38.3 & 44.7 \\
\hline & English & 26439 & 86.1 & 54.1 & 30.5 & 56.6 & 67.7 \\
\hline & Xhosa & 25911 & 67.3 & 26.7 & 16.1 & 32.8 & 35.4 \\
\hline Total & & 54376 & 76.8 & 40.6 & 23.5 & 44.9 & 51.8 \\
\hline
\end{tabular}

Source: Cornelissen, R., 2021, Western Cape systemic testing programme: CPUT engagement, informal presentation, March.

LoLT, Language of Learning and Teaching.

The article begins with an introduction, followed by discussions of the significance of the study, literature review and theoretical framework. The research design and methods follow with results and discussion. The article ends with a succinct conclusion and implications for further research.

\section{Literature review Reading comprehension}

The National Department of Basic Educations (NDBE) Curriculum and Assessment Policy Statement (CAPS 2012:10) for Intermediate Phase (Grades 4-6) document acknowledges that 'reading and viewing' skills are essential as is developing vocabulary. Although this document encourages educators to use a variety of comprehension activities to ensure their learners understand what they read, only phrases are provided, for example: activate prior knowledge, make predictions, visualise, compare, reflect on what you have read. There is no description of why and how teachers use these activities in their daily literacy pedagogy. In a study by Cross and Conn-Powers (2014) a curriculum is defined as a big plan that connects all the content areas in an integrated structure.

Understanding comprehension question skills is a necessary skill that forms a critical part of the reading process (CAPS 2012; Pretorius \& Lephalala 2011). Yet many researchers report on South African teachers who neglect to teach comprehension skills and who lack the depth of content and pedagogic knowledge and interest to teach reading (Marais \& Wessels 2020; Moopelwa \& Condy 2019; Pretorius \& Klapwijk 2016; Spaull et al. 2020). The General Education and Training CAPS Amendments (2019:10) document for Grades 7-9 sets out formal assessment tasks according to Bloom's taxonomy, stating there is a need for 'common language' when discussing the various types of learning. Three cognitive levels are discussed: low order, medium order and high order, with appropriate action words at each level. The document advises that these cognitive levels 'should inform the learning, teaching and assessment strategies of each task'.

Many other developing countries such as Kenya 'face challenges in developing children's literacy skills' (Pretorius \& Spaull 2016:7). In Botswana, Setswana is the national language with English as a second official language. Mokibelo (2016) argues that:
$[T]$ here are other ethnic groups which are Bazezuru and San who encountered problems with language-in-education policy because Botswana's education policy recommends the use of Setswana in lower grades with a switch to English in Standard 2 (Grade 4 in South Africa). (p. 158)

The elimination of other languages creates inequalities and learning barriers for non-Setswana speakers. The Department of Education in Botswana excluded other languages in the lower grades. Yet in South Africa and Kenya, the policy states that learners should use their mother tongue as the LoLT in the Foundation Phase (Mokibelo 2016) only. In South Africa most parents prefer their children to learn in English as early as Grade R. Kenyan learners are experiencing comprehension challenges because learners cannot read and understand words in their mother tongue languages such as Kiswahili. All they have is an imperfect ability to read in English (Piper, Schroeder \& Trudell 2016).

\section{The Progress in International Reading Literacy Study four comprehension skills}

The Grade 7 CAPS (2019) curriuculum expectations are congruent with the assessment items found in the PIRLS study; hence, the researcher (together with her colleagues who had registered for an honours degree) developed and piloted a variety of texts and questions from Grades 1-10. Asking questions of texts is an important way of developing learners' reading skills (Howie et al. 2017:23). The questions began with simple memory recall, and gradually increased in complexity by asking more cognitively higher-order challenging questions. In the higher grades more emphasis is put on the higher-order questions such as 'apply and evaluate' as described by Bloom's taxonomy (CAPS 2019:10). The four PIRLS questions are discussed below.

The first PIRLS comprehension skill is: 'focus on and retrieve explicitly stated information'. This is a comprehension skill that requires learners to:

[I]dentify information that is relevant to the specific goal of reading, including looking for specific ideas, searching for definitions, words or phrases, identifying the setting of a story (e.g. in terms of time or place), and finding the main idea. (Howie et al. 2011:45)

Howie et al. (2017:23) contend that 'focus on and retrieve explicitly stated information allows the reader to locate and understand content that is relevant to the question'. This comprehension skill, in terms of the testing process, requires 
the reader to focus on the text, at the word, phrase and sentence level, for the purpose of constructing meaning (Howie et al. 2017).

The second PIRLS comprehension skill is 'making straightforward inferences'. According to Mullis, Martin and Sainsbury (2016), 'making straightforward inferences' is a skill where learners use hints in a given text to resolve gaps in meaning. During straightforward inferences, learners have the ability to make connections that are implicit and may open to some interpretation based on their perspective (Mullis et al. 2016). Howie et al. (2017:45) state that making 'straightforward inferences' is essential for the 'skilled readers to connect with two or more pieces of information and recognise the relationship even though it is not stated in the text'.

The third PIRLS comprehension skill is 'interpret and integrate ideas and information', which is a reading skill where learners are expected to view 'character actions by comparing and contrasting text information, inferring a story's mood or tone, and interpreting a real-world application of text information' (Howie et al. 2011:45). Mullis et al. (2016:47) substantiate that this is the 'comprehension skill that allows readers to draw on their understanding of the world'. Learners do not focus on only local understandings; rather this comprehension skill allows learners to think globally. The emphasis is on the importance of recalling and linking prior knowledge and lived experiences to the texts.

The fourth PIRLS comprehension skill is 'evaluate critique and examine content, language and textual elements'. It is the highest order and requires readers to process information in a given text and evaluate it (Howie et al. 2011). This advanced cognitive skill enables learners to draw upon their prior knowledge, to reflect and judge the author's language choices and devices for conveying meaning (Mullis et al. 2016). Learners need to find the 'weaknesses in how the text was written or recognise the successful use of the author's craft' (Mullis et al. 2016:21).

In order for Grade 7 learners to become critical and creative thinkers, their teachers are expected to select appropriate texts, and develop questions at the appropriate levels, to support the cognitive development of their learners. Proficiency in reading and viewing using both literary and non-literary texts is encouraged, where learners are expected to recognise different genre structures, identify the audience, purpose and the context of texts. The CAPS (2019:10) assessment tasks require 30\% low-order thinking (memory recall), 40\% medium-order thinking (understanding and applying) and 30\% higher-order thinking (analysing, evaluating and creating).

\section{Conceptual framework}

Two theories guided this study: Vygotsky (1978) in terms of his theory of socio-culture learning and Bloom's (1956, revised 2001) taxonomy of cognitive development. These two theories have been fundamental to this study as they view reading as a constructivist and interactive process (Howie et al. 2017). They stress the significance of social interaction through mediators, a more knowledgeable other or peer, and the importance of developing a stress-free environment. Vygotsky's theory supports the scaffolding of new knowledge, and learners working through their zones of proximal development (ZPD) to develop higher-order thinking and comprehension skills. The 8-week intentionally initiated IP focused on the researcher interacting, mediating and scaffolding higher-order thinking and comprehension skills. During this time, the learners progressed from being dependent to independent thinkers.

Zavershneva and Van der Veer (2018:117, citing Vygotsky 1978) stress that the cognitive processes develop in social interactions with adults or more able peers'. According to Kozulin (2012:2), Vygotsky describes 'learning situations facilitated by a go-between (mediator), [which ensure] that the learners understand the content at stake'. They require the mediator to support learners to reach the next level of cognition or be comfortable to work on their own without the help of a mediator. This is the space where Vygotsky's ZPD apply.

Bloom's taxonomy was selected for this study as the CAPS Amendment (2019:10) document articulates it is an appropriate taxonomy for Grades 7-9. Bloom's taxonomy assists teachers and learners to use a common hierarchical language to describe and classify the different levels of questioning in assessments and learning activities. The six levels of skills (remembering, understanding, applying, analysing, evaluating and creating) are graded in order from the simplest to the most complex and, in this study, the researcher was aware of asking questions from all six levels.

\section{Research paradigm, approach and design}

This study was conducted within an interpretive paradigm, using a qualitative approach and a case study design. An interpretive paradigm was selected. It allowed an in-depth investigation about a particular phenomenon (Yin 2018). A qualitative approach was selected. The researcher wanted to interact extensively with the participants during the IP. According to Lapan, Quartaroli and Riemer (2012) all qualitative research has an interpretive perspective which focuses on uncovering details of the subject under investigation. A case study design was selected. The researcher conducted an in-depth investigation of the case, which was five Grade 7 learners. A case study design allows an in-depth investigation of a phenomenon (Yin 2018).

\section{Setting}

This study was conducted in 2018 at a quintile 5 public primary school with 658 registered learners from Grades R-7, who pay school fees of R2000.00 per annum. The teacher:learner ratio was 1:35. The school's LoLT is English yet $90 \%$ of learners are African home-language speakers 
speaking isiXhosa, French, Swahili, Igboh, Ndebele, Shona and Bemba and only 10\% speaking English and Afrikaans. Many learners have to learn English first before they can learn the curriculum; they do this through a buddy system where stronger learners interpret the work for those who do not understand the LoLT.

\section{Participants}

Purposive sampling targets information-rich participants (Cohen, Manion \& Morrison 2017) and was used to select five struggling Grade 7 learners, and one Grade 7 English teacher and one learner support teacher, both native isiXhosa speaking. Only five learners were selected who had the lowest marks in this class's 2018 WCED baseline tests. The researcher wanted to keep the number small so she could provide extensive interactions and support to each one during the IP. One Grade 7 English teacher was selected since she was currently teaching these learners English. One learning support teacher was selected because she was supporting children as part of the inclusive education programme offered at the school.

\section{Intervention programme}

A carefully planned and executed IP was put in place for a period of 10 weeks, starting from 10 April 2018 to 8 June 2018. The group of five Grade 7 learners met with the researcher five times a week for 30 to $45 \mathrm{~min}$, after school hours. These five learners were aged between 13 and 15 years old and were identified by the researcher as L1, L2, L3, L4, and L5.

Informal pre-tests and post-tests were developed over a period of 3 years by a group of honours students and individually administered as a diagnostic tool to assess reading comprehension skills (Ivanitskaya et al. 2008). The texts, levels and appropriateness of the questions were improved on each year as students critiqued them among themselves. Each text consisted of one comprehension passage with four comprehension questions adapted from the PIRLS document (2016). The researcher chose these four comprehension question types as they are similar to those used by the WCED systemic tests. The researcher had one week to conduct the pre-tests where she read the passages and questions for L1, L2, L4 and L5 who were struggling to read and write on their own, despite being in Grade 7. L3 was a more independent reader so she was able to read and write the answers on her own. The researcher began the pretesting, using the easier passages from Grade 1, systematically moving to the higher grades with more complex texts. The five learners reached 'frustration level' (Burns \& Roe 1989:22) at the Grade 7 passages, where she stopped the pre-testing. In all, five passages were used and 28 questions were asked. The same post-tests were conducted to determine the level of improvement of the five learners' understanding of comprehension skills after the IP.

An intervention schedule (Appendix 1) was planned and followed by the researcher during the IP. The schedule guided the researcher to introduce and teach different literacy higher-order strategies (Appendix 2). The researcher, who was also the Social Science teacher, chose to use a theme for the 10-week IP and this was negotiated and eventually chosen by the participants. They chose 'Slavery' which was adapted from the Grade 7 Social Science History topic: TransAtlantic Slave Trade (Slavery in West Africa) for Term 2. The researcher was able to integrate these literacy comprehension lessons with the English content since she taught them English. The researcher used different comprehension strategies which included: Cloze technique, My turn-Yourturn, Reader's theatre, Vocabulary matching, Anticipation guide, Magic squares, Feature matrix, Think aloud and Comprehension questions (Ntshikila 2021).

For this research project, learners employed a modification chart. They used coloured paper to write their reflections of the lesson of what they had learnt and each week these comments were stuck together on a piece of paper to make a chain (Rosario et al. 2019). The emphasis here was not on writing correct sentences and using correct spelling, but rather for the learners to express their feelings about what they had learnt that day. Learners read out their comments. This taught them to give one another a chance to talk without criticism. Hakim (2017:3) emphasises the importance of an 'environment that is fair where learners are free to answer without critique'. The motivation chart gave the learners an opportunity to express themselves through writing, selfreflection and self-expression (Rosario et al. 2019).

\section{Data collection}

For this research project, the researcher used the results from the following data collection instruments: the learners' exercise books to assess their academic performance in written comprehensions, two interviews and her own participant observation scheduled notes (Creswell 2014; Punch 2014).

Semi-structured interviews allowed the researcher to probe how the two teachers read and discussed passages with their learners, and how the five Grade 7 learners understood the comprehensions (Punch 2014). The researcher was a participant observer in a natural classroom setting where participants were involved in a natural phenomenon of comprehension teaching and learning activities while she made observations without manipulating any variables (Okeke \& Van Wyk 2015). The researcher observed the learning process while she guided her five learners to their zones of abilities and independence during the IP (Vygotsky 1978). She mediated the learning process by asking frequent questions and persuaded her learners to ask questions to encourage discussion (Vygotsky 1978). She purposefully arranged opportunities to conduct cooperative learning to encourage interactions among the five learners. During the IP the learners used exercise books to complete their activities. After every lesson, the researcher completed her observation schedule and the learners reflected on their learning in their modification charts. 


\section{Data analysis}

Data analysis began at the same time as the collection of data. Using both inductive and deductive analysis, she read and re-read the data to make sense of the individual responses (Creswell 2014). She separated the data into smaller and more meaningful sections (Henning, Van Rensburg \& Smit 2004). The themes that emerged, based upon the theories, were colour coded and presented in words and tables (Creswell 2014).

The researcher was also the English teacher for Grade 7 and at all times during the pre-testing and post-testing, she attempted to remain objective, neutral and critical, endeavouring to avoid personal issues of bias or power that might disrupt her analysis of the learners' work. The test passages were marked either right or wrong, limiting the possible influence of the researcher. She was considerate and polite towards all her learners and avoided making biased assumptions (Creswell 2014). To ensure the reliability of the test scripts, scripts were marked twice to double-check for errors. The supervisor independently checked the marking of the scripts. The researcher and the two teachers were native isiXhosa speaking people. The researcher translated and transcribed all interviews transcripts and asked the two teachers to check for accuracy (Creswell 2014).

\section{Ethical considerations}

Ethical conduct goes beyond merely completing an ethical form, especially when working with Grade 7 learners. Once the purpose of the study was explained to all the participants, they were informed that their participation was voluntary and they were free to withdraw from the study at any point. The researcher was hypertransparent throughout the IP period; she built a reciprocal trusting relationship with her learners, by constantly ensuring her learners of the purpose of the study, confidentiality and privacy. The final signed consent forms were safely stored on the researcher's computer. Confidentiality was maintained throughout the study and pseudonyms were used.

\section{Results}

To answer the main research question: 'What effect did an 8-week IP have on the five Grade 7 learners' comprehension abilities?' and the two sub-questions: 'How did the IP assist five Grade 7 learners to develop their higher-order thinking comprehension skills?' and 'How did the learners develop cognitively during the IP?', tables and discussions on each learner are provided. The five tables provide evidence of each learner's cognitive development and their written comments reflecting on their own learning experiences during the 8-week IP. Discussions are provided where the learner's cognitive and social development is discussed juxtoposing international literature and linking to Bloom's taxonomy and Vygotskys social constructivist theory.
TABLE 2: Learner 1.

\begin{tabular}{ll}
\hline Cognitive verbs & Quotations from Learner 1 \\
\hline Remembering & $\begin{array}{l}\text { 'I could not finish my work today because I could not remember } \\
\text { the story that we read today.' (Week 2) }\end{array}$ \\
Understanding & $\begin{array}{l}\text { Anticipation guide: Slaves kidnapped themselves. } \\
\text { 'I 'disagree" because slaves did not kidnapped themselves } \\
\text { because they did not like to be slaves because slaves were beaten } \\
\text { up and treated like animals.' (Week 3) }\end{array}$ \\
Analysing & $\begin{array}{l}\text { 'It was difficult I struggle a lot, at the end I felt so happy when we } \\
\text { finished the activity.' (Week 4) }\end{array}$ \\
Evaluating & $\begin{array}{l}\text { '.. it was the best activity because we all had our own sayings ...' } \\
\text { (Week 5) } \\
\text { 'The slaves were respectful to their master. Masters would treat } \\
\text { slaves badly where they have to work from dawn to dusk.' (Week 6) } \\
\text { 'It was nice to do the Anticipation guide today because it was the } \\
\text { second time it was easier because I'm used to it and we managed } \\
\text { to finish the activity on time.' (Week 7) } \\
\text { 'I could answer all my questions because I know all the stories now } \\
\text { and we discussed everything with my group before and decide } \\
\text { which answers are correct. It was nice to work with my group.' } \\
\text { (Week 8) }\end{array}$ \\
\end{tabular}

In Week 1, L1 began with low-order 'remembering' when she stated: 'I could not remember ...' ', indicating that the historical disadvantages of the past have continued to persist, where L1 was merely asked to repeat information from texts, which she was unable to do. This statement links to Adesoji's (2018:3) definition of Bloom's taxonomy level 1 of 'remembering': 'memory of previously learned material by recalling facts, and concepts'. L1 was unable to 'remember' simple facts from the story, nor was she able to retrieve information from the story. She came into this programme being unable to repeat information. In order for the researcher to understand why L1 could not answer the lower-order comprehension skills, she interviewed both the current Grade 7 teacher, and the past learner support teacher:
Researcher:
How do you check your learner's understanding of explicitly stated questions?
Grade 7 teacher: Learners are too lazy to look back into the story to be able to answer the questions that require them to re-read the story.
Learner support teacher: I would ask those questions during reading and after reading. They normally refer back to the book to see if they can find information they need for the questions and most of them would just read through without understanding the text and would give any answer that they think it's correct.

By Week 3, L1 was beginning to 'understand' the text and was able to challenge the statement by stating: 'I disagree' and she provided her own reasons. Adesoji (2018:3) states that 'understanding' is '... an ability to demonstrate understanding of facts and ideas by organising and comparing'. L1 demonstrated an 'understanding' of the question by providing a relevant answer to the statement.

L1's higher-order thinking became more apparent in Weeks 4-8 when she was able to 'analyse' her own thinking abilities. She reflected that she struggled. Miri, David and Uri (2007) substantiate higher-order thinking skills as the process where open-ended class discussions and inquiry-oriented 
TABLE 3: Learner 2.

\begin{tabular}{ll}
\hline Cognitive verbs & Quotations from Learner 2 \\
\hline Remembering & $\begin{array}{l}\text { 'Mansa Musa kidnapped and sold the slaves to the Europeans.' } \\
\text { (Week 2) }\end{array}$ \\
Understanding & $\begin{array}{l}\text { 'Today's work was nice "agree and disagree". Slaves did not like } \\
\text { to be taken away from their homes because they were separated } \\
\text { from their families.' (Week 3) }\end{array}$ \\
& 'We needed to use our brains for this activity Feature matrix to \\
Analyse & compare characteristics of slaves and masters, but we were able \\
& $\begin{array}{l}\text { to finish because we know the stories about slaves.' (Week 5) } \\
\text { 'We did Readers theatre and acting was nice as it was my first } \\
\text { time doing a role play of the story. I learned a lot of the slave life } \\
\text { in plantations and I was sad.' (Week 6) }\end{array}$ \\
'I felt good today because we managed to finish on time this \\
time because we worked together and discussed and we also \\
tried out many answers, but at the end we managed to finish on \\
time I felt good about our small class.' (Week 7) \\
$\begin{array}{l}\text { 'I like this day I was not shy on My turn your turn because the } \\
\text { activity taught me a lot about prediction, read aloud and paired } \\
\text { reading because we have to think and share our own ending, say } \\
\text { our thinking on the story as to why slaves were not allowed to } \\
\text { speak their own and how life would be if they were not } \\
\text { separated from their siblings. I had to talk a lot in all our activities } \\
\text { and the activities taught me a lot and it makes me understand } \\
\text { the stories.' (Week 8) }\end{array}$ \\
\hline
\end{tabular}

experiments happen, learners are able to analyse, evaluate and synthesise. During the last week, L1 was able to, together with her group, construct her own meanings from the texts, interpret, evaluate and judge the values and ideas by providing their own combined reflections and opinions. Vygotsky (1978), cited by Zavershneva and Van der Veer (2018:117), stresses that the basic role of interaction in the development of a child is that the cognitive processes develop in social interactions with adults or more able peers'.

From the data presented, there are examples of the development of L2's cognitive processing skills. L2 began with lower-order thinking in Week 2. She remembered a fact from the written text.

In Week 3, L2 was beginning to 'understand' the given information in the text and explained that 'slaves did not like to be slaves because they were taken away from their homes and families'. To explore how the learners had been taught the skill of vocabulary and inference making, the researcher asked the following question:

Researcher:

Grade 7 teacher:

Learner support teacher: We also look at inferences where we draw information from the story to explain maybe linking characters to real life characters. ... I also tried to analyse to sort of evaluate the story to try to relate with their everyday life.
TABLE 4: Learner 3.

\begin{tabular}{|c|c|}
\hline Cognitive verbs & Quotations from Learner 3 \\
\hline Remembering & $\begin{array}{l}\text { There were no examples of } L 3 \text { remembering facts from the texts } \\
\text { used during the IP. }\end{array}$ \\
\hline \multirow[t]{2}{*}{ Understanding } & $\begin{array}{l}\text { Anticipation guide: 'Kings did raid weaker neighbours and weaker } \\
\text { neighbours would go and ask for a job.' }\end{array}$ \\
\hline & $\begin{array}{l}\text { L3s response was: 'Mansa Musa took the weaker neighbours } \\
\text { because they did not know how to defend themselves.' (Week 2) }\end{array}$ \\
\hline Analyse & $\begin{array}{l}\text { 'I disagree because slaves did not travelled in a Titanic because it } \\
\text { was long ago there were no big and pretty ship like that. Slaves } \\
\text { travelled in an open ship where men were chained together.' } \\
\text { (Week 3) }\end{array}$ \\
\hline \multirow[t]{3}{*}{ Evaluate } & $\begin{array}{l}\text { Magic square: 'We struggled a lot, but I liked the challenge } \\
\text { because I have to think a lot. I understood most of the words and } \\
\text { I ended up assisting other learners. We struggled at first, but we } \\
\text { managed to complete the activity.' (Week 4) }\end{array}$ \\
\hline & $\begin{array}{l}\text { 'I liked My turn your turn because it gave everybody a chance to } \\
\text { give their own opinion. It was exciting to guess at the beginning. } \\
\text { At the end we went back to check our prediction. I enjoyed at the } \\
\text { end when we make our own ending. It was nice to listen to other } \\
\text { people's ending.' (Week 5) }\end{array}$ \\
\hline & $\begin{array}{l}\text { Readers theatre: 'It was exciting we all had a chance to become } \\
\text { different characters. I enjoyed being a slave than being a master } \\
\text { because masters were very cruel to their slaves.' (Week } 7 \text { ) }\end{array}$ \\
\hline
\end{tabular}

From Week 5, L2 was able to apply her current textual knowledge to new and different situations. Adesoji (2018:4) explains that the "“applying" level is the level where children solve problems to new situations by applying acquired knowledge, facts and rules in different ways'. L2 reflected that they were able to 'use our brains ...' where she was able to transfer the information from the text to a new situation (Feature matrix) and used her knowledge in a different way by comparing characteristics of slaves and masters.

In Week 6, she was able to 'analyse' through participating in the Readers theatre how slaves were punished if they did something wrong in the plantations and how this made her feel 'sad'. Her reflections were becoming more detailed and she was able to analyse her own emotions.

In Week 7, L2 'felt good about our small class'; in this sense she was able to evaluate the group's discussion where they 'tried out many answers'. Vygotsky (1978, cited by Verenkina 2010:17) would say the learners are 'co-constructing knowledge' by reflecting and defending their opinions and judging what is good for the group. Throughout the IP, L2 developed self-confidence stating in Week 8 that she 'was not shy'. Vygotsky (1978, cited by Verenkina 2010:17) states that 'good learning occurs in the Zone of Proximal Development'. Mullis et al. (2016:24) explain that to 'evaluate' constitutes the highest level of cognitive development. The researcher had created a constructivist environment with these five learners, where they were expected to share their opinions; this is very different from the former behaviourist pedagogies used during the apartheid era.

L3's cognitive development improved as the IP progressed. In Week 2, L3 began with lower-order thinking skills of 'understanding'. She showed an ability to understand the given information and to make sense of the new material as Boles, Goncher and Jalayath (2015:5) state: learners 'translate, interpret, and comprehend information based on prior learning'. L3 was able to use her prior knowledge to 'understand' the definitions of words and interpret the text 
TABLE 5: Learner 4.

\begin{tabular}{ll}
\hline Cognitive verbs & Quotations from Learner 4 \\
\hline Remembering & $\begin{array}{l}\text { 'I was sad today because all my answers were not correct today } \\
\text { because I did not remember the details of the story.' (Week 2) }\end{array}$ \\
Understanding & $\begin{array}{l}\text { 'I disagree on the statement because Black slaves did not } \\
\text { kidnapped themselves they were kidnapped by their fellow } \\
\text { Africans.' (Week 3) } \\
\text { 'I like this activity because there were no wrong answers.' } \\
\text { (Week 5) } \\
\text { 'It was fun to describe masters and slaves and this activity made } \\
\text { me understand more and more information about slaves and } \\
\text { masters as we shared our answers.' (Week 6) }\end{array}$ \\
& $\begin{array}{l}\text { 'I felt as if I was not nice during the activity I wanted to cry and it } \\
\text { was very bad because that is how slaves were treated. It was } \\
\text { nice to be a master. I was like a boss and making them sad.' } \\
\text { (Week 7) }\end{array}$ \\
Analysing & $\begin{array}{l}\text { Anticipation guide: 'I like the tricky questions because they were } \\
\text { very hard to answer first, but as I get used to this type of } \\
\text { questions would like to talk all the time.' (Week 8) }\end{array}$ \\
\hline
\end{tabular}

about slave abduction. She agreed with the statement by providing extra knowledge which indicates that she clearly understood the statement.

In Week 3, L3 was beginning to 'analyse' the text: she was able to apply her thinking to new information. For example, during the 'Anticipation guide', she interpreted, classified and explained the different purposes of ships.

In Weeks 4-8, L3 was beginning to evaluate her own learning processes. She presented and defended her opinions by critiquing herself by stating that she 'struggled a lot' but she 'liked the challenge' because she had to 'think a lot' and she 'managed to complete the activity'. These comments are evidence that, by working in a group, L3 was able to learn within the ZPD where she was developing her internal cognitive processes (Vygotsky 1978, cited by Verenkina 2010:17). The researcher purposefully set out to create an enabling literacy environment, very different to the former tradional classroom environments where learners had to mimic their teacher.

From data presented, there is evidence that in Week 2, L4 was 'sad' because she could not remember the details of the story: 'remembering refers to recall or recognition of information, ideas and principles in the approximate form in which they were learned' (Anderson \& Krathwohl 2001).

By Week 3, L4 was beginning to 'understand' and had the ability to question the statement. L4 was able to understand the Anticipation guide activity: she chose to 'disagree' with the statement and supplied her own reason for her disagreement, showing she understood the details of the story. The skill of 'application' refers to the ability to 'select, transfer, use data and principles to complete problems or tasks with a minimum of direction' (Anderson \& Krathwohl 2001:3). L4 was able to apply her new knowledge of slaves, and had a deeper understanding of the rules that existed between masters and slaves. Years later, after the first democratically elected government, these learners were encouraged to debate and discuss sensitive issues such as 'masters and slaves'.

Higher-order thinking refers to learning experiences that enable learners to construct their own thinking skills by
TABLE 6: Learner 5 .

\begin{tabular}{ll}
\hline Cognitive verbs & Quotations from L5 \\
\hline Remembering & $\begin{array}{l}\text { 'The questions was very hard I had to look back at the story } \\
\text { because I could not remember all the things we read.' (Week 2) }\end{array}$ \\
Understanding & $\begin{array}{l}\text { L5 was able to answer the statement: Slaves were chained } \\
\text { because they wanted to chat with each other: Her response was } \\
\text { 'Slaves were chained because they will runaway.' (Week 3) }\end{array}$ \\
Applying & $\begin{array}{l}\text { 'When I did Feature matrix I had to compare slaves and masters } \\
\text { and I manage to answer all my questions and I was happy.' } \\
\text { (Week 6) }\end{array}$ \\
Analyse & $\begin{array}{l}\text { Anticipation guide: 'I was not shy anymore because I was reading } \\
\text { for the group, and the group was not laughing at me.' (Week 7) } \\
\text { 'It was nice to do Magic square again I have to talk a lot and think } \\
\text { a lot to assist the group so that we can get the correct answers.' } \\
\text { (Week 8) }\end{array}$ \\
\hline
\end{tabular}

'inferring, estimating; predicting ... and creative thinking' (Barak \& Dori 2009:2). Between Weeks 7 and 8, L4 was able to 'analyse' her own abilities where she was able to construct her own higher-order thinking through being able to read between the lines (inference) - 'I felt as if I was not nice during the activity' - making connections - 'it was very bad because that is how slaves were treated' - and interacting with the texts - 'I was like a boss and making them sad'.

In Week 8, L4 struggled to answer questions saying 'they were very hard to answer first', but through learning in the ZPD (Vygotsky 1978, cited by Verenkina 2010:17) and scaffolding, in her group she acquired the group's language and made it part of her speech, saying at the end that she 'would like to talk all the time'.

From the data presented, there is evidence that L5 in Week 2 was unable to 'remember' facts from the story: 'I could not remember all the things we read'. This low-order comprehension skill is where learners are required to remember facts from the text for the purpose of constructing meaning (Howie et al. 2017).

During Week 3, L5 was able to, through the Anticipation guide activity, 'understand' and responded appropriately with the statement 'Slaves were chained because they will runaway'. Bloom's taxonomy is clearly articulated in the CAPS Amendment (2019) document, discussing the various cognitive levels at which learners need to perform. Learners begin at the lower cognitive levels until they reach and perform at the higher cognitive levels.

By participating in the Feature matrix, L5 was beginning to perform at the higher-order thinking skills when she was able to apply her own knowledge comparing slaves and masters. In her reflections she stated: 'I manage to answer all my questions and I was happy'. Anderson and Krathwohl (2001:3) state that 'application' refers to the ability to 'select, transfer, use data and principles to complete problems or tasks with a minimum of direction'. It was gratifying to see that L5 was happy to safely discuss issues of social inequalities experienced in the past, in an academic manner.

In Week 6 L5 was able to analyse and reflect on her own learning processes during the activities where she took the lead with her group members: 'I have to talk a lot and think a lot to assist the 
group so that we can get the correct answers'. At this stage of the IP, L5 was not only able to solve the problems by herself, but she was an independent learner; she became the 'more experienced' person (Vygotsky 1978, cited by Verenkina 2010:17).

\section{Conclusion and recommendations}

Despite little research being conducted on Grade 7 higherorder comprehension skills, this researcher identified a gap in the current research and intentionally initiated an IP in which she purposefully set out to explicitly use a variety of literacy strategies to teach higher-order comprehension skills to her five struggling Grade 7 learners. Although many authors have written about teachers not being trained to teach comprehension skills (Spaull et al. 2020; Taylor 2014), this small-scale research project illustrates what can be done, where one teacher (the researcher) met with her supervisor on a regular weekly basis over a period of 10 weeks. They discussed 'how' and 'what' to teach during the IP, purposefully avoiding the former behaviourist pedagogies of the historial past. The results indicate what one teacher achieved when using intentionally focussed pedagogical literacy strategies.

The 10-week IP, comprising the administration and marking of the pre-tests and post-tests and the 8-week IP, had a twofold purpose: firstly, to introduce five struggling Grade 7 learners to a variety of fun comprehension strategies and, secondly, being mindful of challenging them cognitively and developing their ability to think critically. To effect this, learners required explicit teaching and continuous scaffolding to move from lower-order thinking to higherorder thinking skills. The small group of five learners created an environment very different from the mimicking expected in schools before 1994, where the researcher could easily monitor the social interactions and cognitive development of her learners during the IP, being constantly aware that these learners were not learning in their mother tongue language.

Being exposed to, and regularly participating in, the IP enabled learners to develop their higher-order critical thinking skills. A safe and encouraging environment was created with opportunities to grow in confidence, both linguistically and cognitively, even when discussing a sensitive issue such as 'slavery'. This forum allowed learners to get to know their peers better, where they freely engaged in verbal discussions, were able to think for themselves and offered reasoned judgements, hence creating a respectful, democratic group climate. Leaders were allowed to emerge naturally and transform the space into one that was comfortable and safe enough for them to share opinions, comfortably agreeing or disagreeing among themselves, ever mindful of not hurting each other's feelings.

The implementation of the various teaching strategies, taught explicitly, nurtured and supported their ability to successfully infer meanings from texts. Over the weeks, it became easier for learners to make predictions, apply their argumentative skills, with justification, and make connections from the text to their real-life experiences. Asking higher levels of questioning was observed when learners were able to: construct their own knowledge, analyse their abilities, evaluate their own ideas as well as the ideas of others and use appropriate language skills to ask thought-provoking questions. Learners learnt to accept critique, respect the opinions of others and were exposed to different world views which enabled them to think beyond their texts.

The synthesis of the two theories, Vygotsky's (1978) theory of the social constructivism and Bloom's (1956) theory of cognitive development, augured well for this study. Vygotsky's (1978) notion of scaffolding and explicit teaching assisted the learners to courteously participate in literacy debates that challenged the learners' own cognitive development from 'remembering' content in the various texts to 'evaluating' new knowledge (Boles et al. 2015). Throughout the 10-week IP, regularly using the literacy strategies as described in Appendix 2 encouraged the learners to further develop their English language and vocabulary abilities as well as their social interactions. The learners became less stressed and developed through their zones of abilities to become more independent critical higher-order thinkers.

This study was limited to a small group of five struggling Grade 7 learners from low socio-economic environments, although in a quintile 5 school, where isiXhosa was their home language, over a period of 10 weeks. The aim of the study was to develop these learners' higher-order comprehension skills. The findings imply that higher-order comprehension skills can be taught to Grade 7 learners by a well-prepared, motivated and caring teacher, who uses a variety of literacy strategies to engage her learners. Further studies may include using a similar IP to a larger sample over a longer period of time. An important consideration, emerging from this research, is the training of high-quality teachers to explicitly teach higher-order comprehension skills to include all grade levels.

\section{Acknowledgements}

Dr Matthew Curr who language edited this journal article.

\section{Competing interests}

The authors declare that they have no financial or personal relationships that may have inappropriately influenced them in writing this article.

\section{Authors' contributions}

J.L.C., L.M. and H.N.P. acted as supervisors of N.N.'s master's degree and gave input as co-authors while N.N. wrote most of the journal article. 


\section{Funding information}

This research received no specific grant from any funding agency in the public, commercial or not-for-profit sectors.

\section{Data availability}

At the date of submission, this article was extracted from an unpublished master's thesis.

\section{Disclaimer}

The views and opinions expressed in this article are those of the authors and do not necessarily reflect the official policy or position of any affiliated agency of the authors.

\section{References}

Adesoji, A., 2018, 'Bloom's Taxonomy of educational objectives and modification of cognitive levels', Advances in Social Sciences Research Journal 5(5), 292-297. https://doi.org/10.14738/assrj.55.4233

Anderson, L.W. \& Krathwohl, D.R., 2001, A taxonomy for learning, teaching and assessing: A revision of Bloom's Taxonomy of educational objectives, Longman, New York, NY

Barak, M. \& Dori, Y.J., 2009, 'Enhancing higher-order thinking skills among in-service science teachers via embedded assessment', Journal of Science Teacher Education 20(5), 459-474. https://doi.org/10.1007/s10972-009-9141-z

Bassadien, M. \& Spencer, J.P., 2016, 'Gentrification and cultural tourism in the BoKaap, Cape Town', African Journal of Hospitality, Tourism and Leisure 5(1), viewed 25 February 2018 from http://www.ajhtl.com/uploads/7/1/6/3/7163688.

Bloom, B.S., 1956, Taxonomy of educational objectives: Cognitive domain, McKay, New York, NY.

Boles, W.W., Goncher, A. \& Jalayath, D., 2015, 'Categorising conceptual assessments under the framework of Bloom's Taxonomy', in Proceedings of the 26th Annual Conference of the Australian Association for Engineering Education (AAEEE2015), December 2015, School of Engineering, Deakin University, Geelong, pp. 1-8.

Brink, S., Motolo, N. \& Henning, E., 2021, 'Teaching reading in Grade 3: The English first additional language classrooms in six Mpumalanga schools', unpublished research report for the Department of Basic Education, Pretoria.

Burns, P.C. \& Roe, B.D., 1989, Informal reading inventory: Preprimer to twelfth grade, 3rd edn., Houghton Mifflin Company, Boston, MA.

Cohen, L., Manion, L. \& Morrison, K., 2017, Research methods in education, 8th edn., Routledge, London.

Cornelissen, R., 2021, Western Cape systemic testing programme: CPUT engagement, informal presentation, March.

Creswell, J.W., 2014, Research design: Qualitative, quantitative, and mixed methods approach, 4th edn., Sage, London.

Cross, A.F. \& Conn-Powers, M., 2014, 'Making the intentional decision to use an effective curriculum to promote children's learning', Early Childhood Education Journal 42(6), 361-366. https://doi.org/10.1007/s10643-013-0623-4

Eadie, S., Villers, R., Gunawan, J. \& Haq, A.N., 2021, 'South African curriculum: Infusing competencies for a changing world', in F. Reimers, F. Barajas, J. Gunawan \& A. Ha (eds.), An educational calamity. Learning and teaching during the COVID-19 pandemic, pp. 126-145, UNESCO, Paris.

Hakim, B., 2017, 'Use of psychological techniques in classroom management with Arab context', Advances in Language and Literacy Studies 8(2), 85-90. http://dx. doi.org/10.7575/aiac.alls.v.8n.2p.85

Henning, E., Van Rensburg, W. \& Smit, B., 2004, Finding your way in qualitative research, Van Schaik, Pretoria.

Howie, S., Van Staden, S., Tshele, M., Dowse, C. \& Zimmerman, L., 2011, Progress in International Reading Literacy Study (PIRLS): South African children's reading literacy achievement summary report, Centre of Evaluation and Assessment, literacy achievement summary
University of Pretoria, Pretoria.

Howie, S.J., Combrinck, C., Roux, K., Tshele, M., Mokoena, G.M. \& McLeod Palane, N., 2017, PIRLS LITERACY 2016: South African highlights report, Centre for Evaluation and Assessment, Pretoria.

Ivanitskaya, L., DuFord, S., Craig, M. \& Casey, A.M., 2008, 'How does a pre-assessment of off-campus students' information literacy affect the effectiveness of library instruction?', Journal of Library Administration 48(3-4), 509-525. https://doi. org/10.1080/01930820802289649

Kozulin, A., 2012, Vygotsky's educational theory in cultural context, Cambridge University Press, New York.

Lapan, S.D., Quartaroli, M.T. \& Riemer, F.J., 2012, Qualitative research: An introduction to methods and designs, Jossey-Bass/Wiley, Washington, DC.

Marais, A.-M. \& Wessels, E., 2020, 'Investigating the interpretation and implementation of policies that guide the teaching of reading in the Foundation Phase', Reading \& Writing 11(1), a277. https://doi.org/10.4102/rw.v11i1.277
Miri, B., David, B.C. \& Uri, Z., 2007, 'Purposely teaching for the promotion of higherorder thinking skills: A case of critical thinking', Springer Science 37(4), 353-369. https://doi.org/10.1007/s11165-006-9029-2

Mokibelo, E., 2016, 'Implementation of the language-in-education policy and achieving education for all goals in Botswana primary schools', Universal Journal of Education Research 4(1), 157-164. https://doi.org/10.13189/ujer.2016.040120

Moopelwa, Y. \& Condy, J., 2019, 'Strategies for teaching inference comprehension skills to a Grade 8 learner who lacked motivation to read', Per Linguam 35(3), 1-5. https://doi.org/10.5785/35-3-883

Mothata, M.S. \& Lemmer, E.M., 2002, 'The provision of education for minorities in South Africa', South African Journal of Education 22(2), 106-112.

Mullis, I.V.S., Martin, M.O. \& Sainsbury, M., 2016, PIRLS 2016 reading framework, 11-29. Progress in International Reading Literacy Study (PIRLS) 2016: Assessment framework, 2nd edn., International Association for the Evaluation of Educational Achievement (IEA), Boston, MA.

Ntshikila, N.P., 2021, 'Grade 7 learners' understandings of comprehension skills while involved in an intervention programme in a quintile 5 school', Unpublished Masters thesis, Cape Peninsula University of Technology, Cape Town.

Ogbonnaya, U.I. \& Awuah, F.K., 2019, 'Quintile ranking of schools in South Africa and learner's achievement in ability', Statistics Research Journal 18(1), 106-119. https://doi.org/10.52041/serj.v18i1.153

Okeke, C. \& Van Wyk, M.M., 2015, Educational research: An African approach, Oxford University Press, Oxford.

Piper, B., Schroeder, L. \& Trudell, B., 2016, 'Oral reading fluency and comprehension in Kenya: Reading acquisition in a multilingual environment', Journal of Research in Reading 39(2), 133-152. https://doi.org/10.1111/1467-9817.12052

Pretorius, E.J. \& Klapwijk, N.M., 2016, 'Reading comprehension in South African schools: Are teachers getting it, and getting it right?', Per Linguam 32(1), 1-20. https://doi.org/10.5785/32-1-627

Pretorius, E.J. \& Lephalala, M., 2011, 'Reading comprehension in high-poverty schools: How should it be taught and how well does it work?', Per Linguam 27(2), 1-24. https://doi.org/10.5785/27-2-105

Pretorius, E.J. \& Spaull, N., 2016, 'Exploring relationships between oral reading fluency and reading comprehension amongst second language readers in South Africa', Reading and Writing 29(7), 1449-1471. https://doi.org/10.1007/s11145-0169645-9

Punch, K.F., 2014, Introduction to social research: Quantitative and qualitative approaches, Sage, London.

Radhamoney, R. \& Hugo, A.J., 2020, 'An analysis of the results of literacy assessments conducted in South African primary schools', South African Journal of Childhood Education 10(1), a745. https://doi.org/10.4102/sajce.v10i1.745

Rosario, P., Hogemann, J., Nunez, J.C., Vallejo, G., Cunha, J., Rodriguez, C. et al., 2019, 'The impact of three types of writing intervention on student's writing quality', PLoS One 14(7), e0218099. https://doi.org/10.1371/journal.pone.0218099

South Africa. National Department of Basic Education, 2012, National curriculum statement: Curriculum and Assessment Policy Statement (CAPS). 2012. Policy document, Government Printer, Pretoria.

South Africa. National Department of Basic Education, 2019, National curriculum statement: Curriculum and Assessment Policy Statement (CAPS). 2012. Policy document. Amendments, Government Printer, Pretoria.

Spaull, N., Pretorius, E. \& Mohohlwane, N., 2020, 'Investigating the comprehension iceberg: Developing empirical benchmarks for early-grade reading in agglutinating African languages', South African Journal of Childhood Education 10(1), a773. https://doi.org/10.4102/sajce.v10i1.773

Statistics South Africa, 2019, Sustainable development goals: Country report 2019 South Africa, Department of Statistics South Africa, Pretoria.

Taylor, N., 2014, 'Thinking, language and learning in initial teacher education', Presentation to the seminar Academic Depth and Rigor in ITE, University of Witwatersrand, Johannesburg, 30-31 October.

United Nations Educational Scientific, and Cultural Organization (UNESCO), 2018, Global education monitoring report 2019: Migration, displacement and education: Global education monitoring report 2019: Migration,
Building bridges, not walls, 2nd edn., UNISCO, Paris.

Van der Berg, S., Spaull, N., Wills, G., Gustafsson, M. \& Kotze, J., 2016, Identifying binding constructs in education, University of Stellenbosch, Stellenbosch.

Van Staden, S., Bosker, R. \& Bergbauer, A., 2016, 'Differences in achievement between home language of learning and language of learning in South Africa: Evidence from prePIRLS 2011', South African Childhood Education 6(1), a441. https://doi. org/10.4102/saje.v6i1.441

Verenkina, I.M., 2010, 'Vygotsky in twenty-first century research', in J. Herrington \& B. Hunter (eds.), Proceedings of World Conference on Educational Multimedia Hypermedia and Telecommunications, AACE, Chesapeake, VA, pp. 16-25. Available from https://ro.uow.edu.au/edupapers/1022.

Völkel, G., Seabi, J., Cockcroft, K. \& Goldschagg, P., 2016, 'The impact of gender, socioeconomic status and home language on primary school children's reading comprehension in KwaZulu-Natal', International Journal of Environmental Research and Public Health (IJERPH) 13(3), 322. https://doi.org/10.3390. ijerph13030322

Vygotsky, L., 1978, Mind and society: The development of higher mental processes, Harvard University Press, Cambridge, MA.

Yin, R.K., 2018, Case study research and applications: Designs and methods, Sage, Los Angeles, CA.

Zavershneva, E. \& Van der Veer, R., 2018, Vygotsky's notebooks: A selection, Springer, Singapore. https://doi.org/10.1007/978-981-104625-4 


\section{Appendix 1}

\section{Teaching intervention schedule.}

\begin{tabular}{|l|l|l|l|l|}
\hline Week 1 & Week 2 & Week $\mathbf{3}$ & Week 4 \\
\hline Interview with parents & Vocabulary matching & Anticipation guide & My-turn Your-turn \\
\hline Pre-tests/Theme selection & Vocabulary $\mathbf{5}$ & Magic square \\
\hline IP & Comprehension questions & Vocabulary & Vocabulary \\
\hline & Behaviour modification chart & Behaviour modification chart & Behaviour modification chart & Behaviour modification chart \\
\hline Week 6 & Week $\mathbf{7}$ & Week 8 & Week 9 & Week 10 \\
\hline Readers theatre & Anticipation guide & Magic square & Vocabulary matching \\
\hline Vocabulary & Cloze technique & Readers theatre & Vocabulary \\
\hline Reflection & Vocabulary & Comprehension questions & Comprehension questions \\
\hline Behaviour modification chart & Behaviour modification chart & Behaviour modification chart & Behaviour modification chart \\
\hline
\end{tabular}




\section{Appendix 2}

A brief description of nine comprehension strategies used in the IP.

\section{Cloze technique}

During a cloze activity, learners show their understanding of the content of a text by filling in the blank spaces with the correct words. Learners are expected to fill in the missing words using words extracted from the text or words that will make sense and meaning as in the example below:

Fill in the missing words using the words below:

Kidnapped, woman and children, Mansa Musa, weaker, captives, barracoons, captured, chained, red-hot iron

1. Slaves who are would be and led to march for hundreds of kilometers.

2. Kings like , raided their neighbors and sold them.

3. Africans were often by fellow Africans.

4.

5. would also be raided and sold to the European slave traders.

until they are sold.

6. Once they are sold, the slave traders used a to brand them.

\section{My turn - Your turn}

The teacher reads a passage, stops and begins a discussion by saying: 'My turn'. She discusses a particular planned piece of content by verbally asking one of the following questions: predicting, making connections, clarifying, paraphrasing or summarising questions. She then offers her learners the opportunity to give their ideas by saying 'Your turn'. This activity promotes peer-learning where learners read and discuss texts, giving each other time to talk, time to listen, respect each other's opinions at the same time as developing and expanding their vocabulary.

Predicting During the my turn - your turn activity, learners learn to predict the story by reading the title and looking at the pictures to imagine what would happen next.

Making connections Learners connect two or more pieces of information that they read based on their life experiences to their background knowledge and share these connections with each other.

Clarifying Occurs during reading. Learners are expected to look at the title, use keywords, use other words as clues, and become actively involved in the reading text (CAPS 2012). When learners do not understand, the teacher asks them to take turns to stop and think about what they have read.

Paraphrasing/summarising Refers to the summary of the main idea and 'supporting ideas in a point form/paragraph as per the required length' (CAPS 2012:17). The CAPS (2012) document emphasises the importance of summarising to assist learners to remember the main ideas of stories.

\section{Reader's theatre}

Reader's theatre is where learners read and perform a script without memorising lines, and without the use of costumes.

\section{Vocabulary matching}

Matching vocabulary assists learners with understanding words. The activity consists of two columns with only the vocabulary words in the left-hand column (out of context) and the meanings in the right-hand column, but in a mixed up, random order. The learners match the words to the meanings as in the example below. 


\section{Slave abduction}

Match the word in the left column with the meaning in the right column.

\begin{tabular}{|l|l|l|}
\hline Vocabulary words & $\begin{array}{l}\text { Write the number next to the correct meaning } \\
\text { of the word }\end{array}$ & Definition \\
\hline 1. Kidnapped & & a. A temporary place to keep slaves \\
\hline 2. Raided & & b. People who had been captured \\
\hline 3. Captives & & c. Centers from which slave traders work \\
\hline 4. Bases & & d. To attack or invade \\
\hline 5. Barracoons & & e. Someone taken away illegally and kept them as prisoners. \\
\hline
\end{tabular}

\section{Anticipation guide}

Anticipation guides are a reading strategy, which increases learner's prior knowledge and the ability to interact with texts in any educational setting. This comprehension strategy can be used by groups of five, where learners read or listen to a story. On a page the teacher writes controversial statements in the left-hand column. There are five other columns for each learner where they respond to the statement circling whether they agree (A) or disagree (D) with the statement, emanating from the text, in the left column and discuss it with the members of the group. The statement is read and the learners explain why they are choosing to circle $\mathrm{A}$ or $\mathrm{D}$. Learners are required to use the same sequence in all questions as in the example below.

\section{Slave barracoons}

In groups of five, read the statement in the left column and discuss it with each other. Once you have all shared your ideas, then each person circles ' $A$ ' (Agree) or ' $D$ ' (Disagree) on their own sheet of paper reflecting on each person's points of view. Move onto discussing the next question.

\begin{tabular}{|c|c|c|c|c|c|}
\hline Statements & Name....... & Name....... & Name....... & Name....... & Name....... \\
\hline $\begin{array}{l}\text { 1. Black slaves enjoyed being kidnapped from their } \\
\text { homes. }\end{array}$ & AD & AD & AD & AD & AD \\
\hline 2. Slaves kidnapped themselves. & $A D$ & $A D$ & $A D$ & $A D$ & $A D$ \\
\hline 3. Africans were separated from their siblings. & $A D$ & $A D$ & $\mathrm{AD}$ & $A D$ & $A D$ \\
\hline 4. Slaves fight back because they had guns. & AD & $A D$ & $\mathrm{AD}$ & $\mathrm{AD}$ & $A D$ \\
\hline $\begin{array}{l}\text { 5. Kings raided the weaker neighbors, neighbours would } \\
\text { go and ask for a job. }\end{array}$ & AD & AD & AD & AD & $A D$ \\
\hline 6. Slaves were using buses to travel to the barracoons. & $A D$ & $A D$ & $A D$ & $A D$ & $A D$ \\
\hline $\begin{array}{l}\text { 7. Slaves were chained because they wanted to chat } \\
\text { with each other. }\end{array}$ & $A D$ & $A D$ & $A D$ & $A D$ & $A D$ \\
\hline 8. Barracoons were brick houses used to keep slaves. & $A D$ & $\mathrm{AD}$ & $\mathrm{AD}$ & $\mathrm{AD}$ & $A D$ \\
\hline 9. Slaves were given labels with branding iron. & AD & $A D$ & $\mathrm{AD}$ & $A D$ & $A D$ \\
\hline $\begin{array}{l}\text { 10. They travelled with Titanic ship each slave had } \\
\text { beautiful cabins/rooms. }\end{array}$ & AD & AD & $A D$ & AD & AD \\
\hline
\end{tabular}

\section{Magic squares}

A magic square activity is a square grid with a special arrangement of numbers in it. These numbers are special as the horizontal and vertical numbers add up to the same number. On a sheet of paper there will be two columns, one for content area vocabulary and one for definitions. The learners are asked to match vocabulary (letters) with definitions (numbers) which are in a mixed-up order. The students then write the number of a definition in the proper space (denoted by the letter of the term) in the 'magic square answer box'. This total forms the puzzle's 'magic number'. Students add up the rows and columns to check if they have the same number for each horizontal and vertical. If not they should go back to the vocabulary and definitions to re-evaluate their answers. See the example below. 
The vocabulary words are in the left of the column. Find the correct meaning in the right column but in a mixed-up order.

\begin{tabular}{|c|c|c|c|}
\hline A & Market & 1 & Found in a newspaper \\
\hline B & Advertised & 2 & Slaves specials \\
\hline C & Auction & 3 & Person who buy slaves \\
\hline $\mathrm{D}$ & Bidder & 4 & Owned by the master \\
\hline $\mathrm{E}$ & Brought & 5 & Paying money for slaves \\
\hline $\mathrm{F}$ & Offered & 6 & Public sale which slaves are sold \\
\hline G & Slave & 7 & Person who has the most money \\
\hline $\mathrm{H}$ & Sold & 8 & Similar to a shop \\
\hline 1 & Sales & 9 & Purchase \\
\hline
\end{tabular}

In the square below put the corresponding number in each block.

\begin{tabular}{|l|l|l|}
\hline A & B & C \\
\hline D & E & F \\
\hline G & H & I \\
\hline
\end{tabular}

\section{Feature matrix}

The Feature matrix is a strategy that compares or classifies characteristics as in the example below.

Compare characteristics of slaves and masters

\begin{tabular}{|l|l|l|}
\hline Questions & Slaves & Masters \\
\hline How slaves would be treated? & & \\
\hline What clothes would they wear? & & \\
\hline What food would they eat? & & \\
\hline What religion would they follow? & & \\
\hline What language would they speak? & & \\
\hline
\end{tabular}

\section{Think - Aloud}

This strategy involves the teacher vocalising the internal thinking that she employs while reading a text. She purposefully interrupts herself, during modelled reading to assist the learners' comprehension. First the teacher reads, then stops to share her thinking and invites learners to add to the thinking. The intention is that think alouds make explicit the cognitive processes that literate people use while reading and making sense of a text. Teachers can use this approach to role model higher-order skills such as: predicting, clarification, making connections, inferencing, and summarising skills.

\section{Comprehension questions}

The teacher reads a passage and then invites the learners to respond. On a piece of paper, both the questions and the answers are provided, the learners underline the correct type of question - as in 1-4 below:

1. Retrieve explicitly stated information

2. Make straightforward inferences

3. Interpret and Integrate ideas and information

4. Evaluate and examine content, language and textual elements

\section{Question: Would you hurt any of your friends?}

Answer: I would protect my friends as far as possible

1. $2 . \quad 3$. 
2. Question: What would happen if captives fought back their kidnappers?

Answer: They would be punished by death
1.
2.
3.
4.

3. Question: Explain why Kings like Mansa Musa raided weaker neighbours and sold them

Answer: He had the largest and richest empire

1. $2 . \quad 3$.

4. Question: What do you not like about this text?

Answer: I do not like the fact that slaves were taken away from their families and treated so badly.

1. $2 . \quad 3$. 